outbreak of $C$. difficile. ${ }^{2}$

That proton pump inhibitors should be a risk factor ${ }^{3}$ is of interest in this regard. ${ }^{4}$ These drugs stimulate cation-dependent short-circuit currents in the colonic mucosa, possibly by converting the vanadate-sensitive $\mathrm{H}+/ \mathrm{K}+-\mathrm{ATP}$ ase into an electrogenic cation transporter. ${ }^{5}$ Should the demand for energy from ATP (adenosine triphosphate) hydrolysis so induced exceed the capacity for ATP resynthesis, the action might precipitate an aerobic energy deficit or unreversed ATP hydrolysis similar to that developing for different reasons in ischemic colitis that occurs as a complication of abdominal aortic surgery. As in C. difficile colitis, the passage of liquid, bloodstained stools is an established feature of this condition.

\section{Richard Fiddian-Green}

Former Professor of General Surgery

University of Massachusetts

Worcester, Mass.

\section{References}

1. Fiddian-Green RG. $C$ difficile colitis: is it really ischaemic colitis? [letter]. Gut 2004. Available: http://gut.bmjjournals.com/cgi/eletters/53/5 1673\#417 (accessed 2004 Oct 26). Electronic letter published online only.

2. Eggertson L, Sibbald B. Hospitals battling outbreaks of $C$. difficile. CMA7 2004;171(1):19-21.

3. Dial S, Alrasadi K, Manoukian C, Huang A, Menzies D. Risk of Clostridium difficile diarrhea among hospital inpatients prescribed proton pump inhibitors: cohort and case-control studies. CMA7 2004;171(1):33-8.

\section{Mécanisme de présentation des lettres}

Le site amélioré des cyberlettres du JAMC est désormais le portail de réception de tous les textes destinés à la chronique Lettres. Pour rédiger une cyberlettre, consultez un article sur le site www.jamc.ca et cliquez ensuite sur le lien «Lettres électroniques : répondre à cet article», dans la boîte en haut à droite de l'article. Toutes les cyberlettres seront étudiées pour une éventuelle publication dans le journal imprimé.

Les lettres répondant à un article publié dans le JAMC sont plus susceptibles d'être acceptées pour publication imprimée si elles sont présentées dans les deux mois de la date de publication de l'article. Les lettres acceptées pour publication imprimée sont révisées en fonction du style du JAMC et raccourcies au besoin (elles doivent habituellement compter au maximum 250 mots). whether progression to a more fulminant course occurred because of a combination of an infectious with an ischemic insult, with the following possible scenario: severe diarrhea from $C$. difficile causes dehydration and relative hypotension, which leads to either global or localized bowel ischemia, which then acts as a motor for a systemic inflammatory response syndrome and a more fulminant presentation. The possibility that the reverse occurs - prior relative intestinal ischemia leading to increased susceptibility to the toxin and a more severe presentation - is intriguing, especially in light of a report by Dallal and associates. ${ }^{5}$ These authors found that cardiothoracic procedures and vascular surgery were the most common operations that preceded fulminant $C$. difficile colitis, although this observation may simply reflect the high rate of these procedures.

I believe that the current outbreak is primarily infectious, since the observation of bloody diarrhea has been the exception rather than the rule; nonetheless, the contribution of an ischemic insult should be considered in the more severe forms. At this point, many unanswered questions remain, but hopefully continued research in this area will help clinicians to decrease the incidence of infection and improve patient outcomes.

\section{Sandra Dial}

Departments of Critical Care and

Respirology

McGill University

Montréal, Que.

\section{References}

1. Dial S, Alrasadi K, Manoukian C, Huang A, Menzies D. Risk of Clostridium difficile diarrhea among hospital inpatients prescribed proton pump inhibitors: cohort and case-control studies. CMA7 2004;171(1):33-8.

2. Martin RM, Dunn NR, Freemantle S, Shakir S The rates of common adverse events reported during treatment with proton pump inhibitors used in general practice in England: cohort studies. Br f Clin Pharmacol 2000;50:366-72.

3. Thomson RD, Lestina LS, Bensen SP, Toor A, Maheshwari Y, Ratcliffe NR. Lansoprazole-associated microscopic colitis: a case series. Am 7 Gastroenterol 2002;97(11):2908-13.

4. Klingensmith ME, Neville LJ, Delpire E, Wolfe MM, Sybel DI. Gastrin-mediated effects of omeprazole on rat colon mucosa. Surgery 1999;126(2):272-8. 
5. Dallal RM, Harbrecht BG, Boujoukas AJ, Sirio CA, Farkas LM, Lee KK, et al. Fulminant Clostridium difficile: an underappreciated and increasing cause of death and complications. Ann Surg 2002;235:363-72.

Competing interests: None declared.

DOI:10.1503/cmaj.1041678

\section{Corrections}

$\mathrm{T}$ he last name of the author of a recent Left Atrium article ${ }^{1}$ was published incorrectly. The author's name is Alejandro R. Jadad. The online version was corrected.

\section{Reference}

1. Halifax ND, Gray R, Jadad AR. Self-portraits of illness: the gift of the gaze. CMA7 2004;171 (7):764-5.

DOI:10.1503/cmaj.1041680

$\mathrm{I}_{\mathrm{t} t \mathrm{i}}^{\mathrm{n}}$ 2 recent articles, ${ }^{1,2}$ the authors' omitted relevant information regarding their competing interests; their interests should have been listed as follows:

None declared for Peter Bogaty or Blair O'Neill. Paul Armstrong has received research funding from HoffmanLa Roche, Aventis and Boehringer Ingelheim, and educational and consultant funding from Hoffmann-La Roche and Aventis. Paul Dorian has received speaker fees from Guidant Corp., Medtronic Inc. and St. Jude Medical Inc. Dr. Buller has received research support from Guidant Corp. and Cordis Johnson \& Johnson, consultant fees from Guidant Corp. and Aventis, and speaker fees from Hoffman-La Roche.

\section{References}

1. Bogaty P, Buller CE, Dorian P, O'Neill BJ, Armstrong PW. Applying the new STEMI guidelines: 1. Reperfusion in acute ST-segment elevation myocardial infarction. CMAF 2004;171 (9):1039-41.

2. Dorian P, Bogaty P, Buller CE, O'Neill BJ, Armstrong PW. Applying the new STEMI guidelines: 2. Disturbances of cardiac rhythm after ST-segment elevation myocardial infarction. CMA7 2004;171(9):1042-4.

DOI:10.1503/cmaj.1041681

$T^{h}$ he authors of a recent research article $^{1}$ mistakenly omitted Joelle Bradley from their list of authors. She contributed to the development of the questionnaire, study design and data collection. At the time of her contribution she was a medical student at the University of Calgary. She has recently finished her residency in family medicine at the University of Alberta.

\section{Reference}

1. Wright B, Scott I, Woloschuk W, Brenneis F, Bradley J. Career choice of new medical students at three Canadian universities: family medicine versus specialty medicine. CMAF 2004:170(13):1920-4.

DOI:10.1503/cmaj.1041682

$\mathrm{T}$ he DOI published in a recent news item ${ }^{1}$ was mistakenly listed as $10.1503 / \mathrm{cmaj} .1041056$. It should be 10.1503/cmaj.1041506.
Reference

1. Kondro W. New standard of disclosure set for clinical trials. CMA7 2004;171(8):839.

DOI:10.1503/cmaj.1041685

Deference 19 from a recent commentary ${ }^{1}$ was missing information. The complete reference should have been listed as: Tri-Council policy statement: ethical conduct for research involving humans. Ottawa: Medical Research Council of Canada; Natural Sciences and Engineering Research Council of Canada; Social Sciences and Humanities Research Council of Canada; 2003 Jun. Article 7.3. Available: www.pre.ethics.gc.ca/english/pdf /TCPS\%20June2003_E.pdf (accessed 2004 Oct 27).

\section{Reference}

1. Ferris LE, Naylor CD. Physician remuneration in industry-sponsored clinical trials: the case for standardized clinical trial budgets. CMAF 2004;171(8):883-6.

DOI:10.1503/cmaj.1041683

Tn a recent article ${ }^{1}$ there was a typo1 graphical error pertaining to the number needed to treat (NNT) for the SCD-HeFT trial. It should read NNT 14 rather than 1.

\section{Reference}

1. Davis DR, Tang ASL. Implantable cardioverter defibrillators: therapy against Canada's leading killer. CMA7 2004;171(9):1037-8.

DOI:10.1503/cmaj.1041689 